DOI: $10.2478 /$ pof-2018-0035

VOLUME 10, ISSUE 3, 2018

ISSN: $2036-5438$

\title{
From procedural disagreement to joint scrutiny? The Interparliamentary Conference on Stability, Economic Coordination and Governance
}

by

Valentin Kreilinger*

Perspectives on Federalism, Vol. 10, issue 3, 2018 


\section{Abstract}

The provision of Article 13 TSCG to create an Interparliamentary Conference was the starting point for long discussions after which national parliaments and the European Parliament eventually reached a compromise. This article pursues a two-fold objective: It first examines the different phases of interparliamentary negotiations from 2012 to 2015. On the basis of a distinction between three competing models for interparliamentary cooperation, the article shows that the two models of EP-led scrutiny and creating a collective parliamentary counterweight did not prevail: Parliaments agreed that the new Interparliamentary Conference on Stability, Economic Coordination and Governance (SECG) would follow the 'standard' interparliamentary conference (COSAC model). In terms of national parliaments' actual participation, the lowest common denominator compromise has not changed the numbers of participating MPs: Attendance records are stable over time, the size of national delegations continues to vary and participating MPs are still twice as likely to be members of Budget or Finance committees than to be members of European affairs committees.

Key-words

European Union, national parliaments, Economic Governance, interparliamentary cooperation 


\section{Introduction}

In Europe's post-crisis Economic Governance, interparliamentary cooperation between national parliaments and the European Parliament (EP) takes place in an Interparliamentary Conference which was established on the basis of Article 13 of the Treaty on Stability, Coordination and Governance (TSCG) in 2013. Interparliamentary cooperation is a possible remedy against shortcomings in the parliamentary control of EU Economic Governance. During the negotiations about the TSCG the provision to establish an Interparliamentary Conference was included after the French Parliament, in particular, had insisted to put such a provision into the treaty. As a consequence, the TSCG did not only strengthen the coordination and surveillance of fiscal and economic policies, but also provided for the creation of an Interparliamentary Conference in order to 'discuss budgetary policies and other issues covered by this treaty. ${ }^{\text {,I }}$

Composed of representatives of the relevant committees of the European Parliament and national parliaments, the Conference has met twice a year since October 2013 and was named the 'Interparliamentary Conference on Stability, Economic Coordination and Governance' (SECG) in 2015. Executive dominance in fiscal and economic policies might motivate national parliaments and the European Parliament to work together and 'exert countervailing power, both individually and collectively' (Curtin 2014: 30), but in the early years of its existence the Conference has not been able to meet expectations. Due to disagreements between national parliaments and the European Parliament, the Conference was busy negotiating its Rules of Procedure for more than two years instead of addressing the fiscal and economic challenges of the EU. The challenges are similar to those encountered in other policy areas: The general relationship between the two parliamentary levels has been characterised by conflict and rivalry, rather than cooperation (Martucci 2017; see Neunreither 2005).

The Rules of Procedure adopted by the SECG Conference in November 2015 reflect a lowest common denominator compromise about the role that this Conference should play. But the compromise allows to accommodate very different parliamentary preferences about what functions and tasks the Conference should fulfil and the SECG Conference has embarked on a path to becoming a venue for the joint scrutiny of EU Economic 
Governance, as the participation records and conduct of its meetings show. In EU affairs, joint scrutiny basically means that Members of national parliaments (MPs) and the European Parliament (MEPs) meet, exchange, and cooperate in order to address the information asymmetries that they have vis-à-vis other EU institutions as well as national governments, and to engage in a collective dialogue with representatives of this executive branch.

Methodologically, this article pursues a qualitative examination of the negotiations about the institutional design of the SECG Conference on the basis of a variety of written sources and participating observation (Schöne 2005) at several meetings of the Conference. In addition to that, it analyses attendance records of the Conference from 2013 to 2018.

After briefly examining the history of Article 13 TSCG (see section 2), this article puts forward three competing models for interparliamentary cooperation as the analytical framework for studying the emergence of the SECG Conference (see section 3). It asks how and in what direction the legal basis, rules and practices shape the functioning of the SECG Conference? and examines the parliamentary preferences and negotiations concerning the institutional design of this arena of interparliamentary cooperation. The Rules of Procedure of the SECG Conference, adopted in Luxembourg on 10 November 2015, are, for now, the basis for the functioning of the Conference (see section 4). The model that has prevailed is a COSAC-style venue (see section 5) whose attendance is stable, but unequal, and which attracts both members of Budget or Finance committees and European affairs committees (see section 6).

\section{The creation of an Interparliamentary Conference under Article 13 TSCG}

The theoretical rationale behind resorting to interparliamentary cooperation in EU Economic Governance can be found in the need to respond to the use of intergovernmentalism in that area: '[T] he European Council needs to be balanced with an equally strong voice of parliamentary representation' (Neyer 2014: 135) and 'the intergovernmental logic brings with it an interparliamentary balancing' (Fabbrini 2013: 12). Article 13 TSCG is the product of intergovernmental negotiations in December 2011 and January 2012 and has undergone significant changes during the negotiating process, 
revealing difficulties of Member States in reaching an agreement on this point (Kreilinger 2013: 8-10). The original objective of the provision was that national MPs meet regularly and that this would happen in close association with the European Parliament. During the negotiations, Article 13 TSCG was completely revised twice and only the later drafts of the TSCG made an explicit link to the existing interparliamentary formats and Protocol No 1 (Kreilinger 2013: 10). Article 13 TSCG was finally agreed by the Contracting Parties as follows:

As provided for in Title II of Protocol (No 1) on the role of national Parliaments in the European Union annexed to the European Union Treaties, the European Parliament and the national Parliaments of the Contracting Parties will together determine the organisation and promotion of a conference of representatives of the relevant committees of the European Parliament and representatives of the relevant committees of national Parliaments in order to discuss budgetary policies and other issues covered by this Treaty. ${ }^{\mathrm{II}}$

This treaty article explicitly entrusted national parliaments and the European Parliament to 'determine the organization and promotion' of the Conference.

The specific legal basis for interparliamentary cooperation in the EU can be found in Protocol No 1, Title II on Interparliamentary Cooperation. The prevailing legal interpretation sees an equal involvement of the European Parliament and national parliaments on the basis of Article 9 Protocol No $1^{\mathrm{III}}$, taking decisions by consensus. Sector-specific conferences 'on specific topics' (as provided for in Article 10 Protocol No 1) would then be set up on the basis of principles that were agreed by the Speakers' Conference by consensus (and not by COSAC which could theoretically decide by a majority of three-quarters). Some national parliaments, in particular a group of chairpersons of European affairs committees led by the Danish Folketing (see section 4, below), however, argued that Article 10 Protocol No 1 would empower COSAC to establish sector-specific interparliamentary conferences and did not see the Speakers' Conference in such a role (see Esposito 2016: 326-327; Folketing 2013).

There is a 'small but growing body of research on inter-parliamentary cooperation between the EU's national legislatures (and the European Parliament)' (Raunio 2014: 554) which has a long tradition in the EU and evolved over time with the emergence of policyspecific formats such as the SECG Conference (Hefftler and Gattermann 2015: 95-101). 
From early studies on inter-parliamentary cooperation (Bengtson 2007; Costa and Latek 2001; Larhant 2005; Neunreither 1994, 2005), the literature has specialised into more detailed analyses of interparliamentary conferences. But the line of argument on conflict and cooperation [between the national parliaments and the EP] has been extended' (Rozenberg and Hefftler 2015: 21), when two new policy-specific interparliamentary conferences (on CFSP/CSDP and Economic Governance) were created in 2012/2013. Setting them up 'has been all but smooth' (Fasone and Lupo 2016: 345).

\section{Competing models for the relationship between national parliaments and the European Parliament in EU Economic Governance}

One of the main political reasons behind promoting (inter)parliamentary involvement in EU Economic Governance is the perceived lack of national ownership of national (economic) reforms. Even though in the European Semester most national governments submit the annual National Reform Programme to their parliament before transmitting it to the European Commission (Hallerberg et al. 2018; Raimla 2016), national parliamentarians often see economic reforms as being 'imposed' by Brussels. At the same time, it is also true that they (and their governments) sometimes lose control of the different multi-level coordination and surveillance processes.

As explained below, different models for a better parliamentary input in EU Economic Governance have been debated. This article agrees that greater interaction between the national level and EU level via an Interparliamentary Conference could, for instance, help create better national ownership of the European Semester through a greater dialogue between parliamentarians and the different EU Economic Governance actors and bodies. The added value of this Conference cannot be found in decision-making powers, but in deliberation that informs and potentially legitimises the overall process (Jančić 2016: 245). Interweaving the levels of governance would also generally facilitate the coordination of economic and budgetary policies: If national parliaments were aware of indicators such as the aggregate fiscal stance of the Euro area, if they debated them at the EU level and then had the task to transpose these orientations in their respective national parliaments, one could hope for stronger coordination and convergence (Kreilinger and Larhant 2016: 7). If diverse political views are represented in an interparliamentary conference, this could also 
lead to greater politicisation of these topics (Hix 2014). But as long as fiscal and economic policy decisions are seen as numeric rules (such as the obligation of the balanced budget rule of the Fiscal Compact) and not as political choices, their acceptance in national political arenas will remain greatly reduced (Schmidt 2015). In an interparliamentary setting (some of) these problems could be tackled. The implementation of the legal provision of Article 13 TSCG was, however, complicated by the existence of several competing institutional designs that different political actors had in mind for the Conference.

The European Parliament has traditionally been sceptical about enhancing the role of national parliaments, fearing that this could undermine its position (Crum and Fossum 2013a: 255). Already back in 2012 it had described the possibility of creating a mixed parliamentary body as 'both ineffective and illegitimate' and insisted that only itself, 'as parliamentary body at the Union level for a reinforced and democratic EMU governance' (European Parliament 2012: 19), had full democratic legitimacy to exercise control in that area. For the European Parliament, nobody else is able 'to stress the points of convergence and the shared interests amongst the parliamentarians and citizens of different Member States' (Fasone 2012: 18). But since the European Parliament only has very limited legislative powers in EU Economic Governance (Crum 2018: 277) and national parliaments have kept prerogatives such as the adoption of national budgets, economic reforms and holding national governments accountable, it is difficult to see how the European Parliament could be solely responsible for scrutinising the aggregate fiscal stance of the Euro area or decision-making in the ESM (respectively a European Monetary Fund), whose resources come from national sources in the form of initial capital and guarantees (Kreilinger and Larhant 2016: 9). Unsurprisingly, the European Parliament does not subscribe to arguments in favour of strong interparliamentary cooperation in EU Economic Governance.

Many national parliaments are, in return, suspicious of giving a greater role to the European Parliament (Winzen et al. 2015; Winzen 2017: 121-175) and/or of including it in interparliamentary cooperation beyond the absolute minimum. Some of them could ultimately even imagine pursuing cooperation among national parliaments in EU Economic Governance without the European Parliament (Kreilinger 2014: 67), but over time national parliaments' involvement has not developed into a direct EU role (see Winzen 2017). 
The Lisbon Treaty stipulates that national parliaments 'contribute actively to the good functioning of the Union [...] by taking part in the interparliamentary cooperation between national Parliaments and with the European Parliament. ${ }^{\text {IV }}$ The legal provisions do not prescribe a particular institutional design for the interparliamentary cooperation. This helped to agree on the wording of Article 13 TSCG in early 2012, but Protocol No 1, Title II on Interparliamentary Cooperation allows for two different interpretations with respect to the role of the EU Speakers' Conference and COSAC (see section 2).

Over time, the fundamental preferences of national parliaments and the European Parliament (about how the parliamentary scrutiny of Economic Governance should be organised) have not fully converged. This confirms earlier research under the lenses of the conceptual frameworks of the 'Multilevel Parliamentary Field' (Crum and Fossum 2009) and the 'Euro-national parliamentary system' (Lupo and Fasone 2016). As they tried to attribute tasks and competences to an interparliamentary conference in Economic Governance, national parliaments, the European Parliament and other actors ${ }^{\mathrm{v}}$ stuck to three competing models which are developed in the following. These models provide the framework against which this article assesses the debates and negotiations about the SECG Conference.

According to the first model for the relationship between national parliaments and the European Parliament in EU Economic Governance, scrutiny in the area of Economic Governance should take place under the sole and unique leadership of the European Parliament (see Fasone 2012: 18). The European Parliament would occasionally invite national parliaments to join MEPs in Interparliamentary Committee Meetings of the Committee on Economic and Monetary Affairs or at the European Parliamentary Week as part of the European Semester. National parliaments are supposed to scrutinise their national government in EU Economic Governance without playing a particular role at the EU level or intervening collectively. The provision of Article 13 TSCG would mostly be fulfilled through an expansion of the existing Interparliamentary Committee Meetings.

Under the second model for the relationship between national parliaments and the European Parliament in EU Economic Governance, the Interparliamentary Conference is a COSAC-style venue for the exchange of information and best practices (see Kreilinger 2013). ${ }^{\text {VI }}$ Proponents of this model wanted to build upon the example of COSAC and, like in the case of the Interparliamentary Conference on CFSP/CSDP, they created a policy- 
specific Conference for Economic Governance. Parliamentary scrutiny would still be conducted by each national parliament at the national level and by the European Parliament at the EU level, but the Interparliamentary Conference would allow them to discuss budgetary issues and possibly parliaments would have better information for their individual scrutiny activities.

In the third model (collective parliamentary counterweight), Article 13 TSCG would provide the basis for creating a powerful interparliamentary body that could effectively scrutinise and act as a counterweight to executive decision-making in the area of Economic Governance (Curtin 2014: 30). After all, besides Article 13 TSCG, the TSCG and the ESM Treaty do 'little or nothing to anchor new regulatory functions for the Union in democratic institutions' (Dawson and de Witte 2013: 834). Establishing a collective parliamentary counterweight would possibly also require a more exclusive component for the Euro area, in which the national parliaments of Member States whose currency is the Euro would coordinate their activities and exercise parliamentary control at the level of the Euro area. ${ }^{\text {VII }}$ Under this model, parliamentary scrutiny would be pooled and shared, based on Article 13 TSCG. But Ben Crum and John E. Fossum already stressed in 2013 that

[i]nterparliamentary coordination suffers from the major limitation that it remains inherently fragmented. However much parliaments coordinate, they are unlikely to add up to a single coherent voice that can control the actual decisions adopted by the collective of governments that they scrutinise (Crum and Fossum 2013b: 3).

Many of the actors involved in the negotiations on the procedural arrangements for the SECG Conference, in particular the Rules of Procedure, have aligned with the key characteristics of one model, for instance in letters, reports or working papers. Their preferences for organising interparliamentary cooperation can therefore, in most cases, be classified as close to either EP-led relations, to a COSAC-inspired conference or to creating a collective parliamentary counterweight.

Some contributions have pointed out that parliamentary preferences would align along only two models: Winzen (2017: 163-164) distinguishes support for and opposition against a broad mandate of the Conference while other contributions classified parliamentary preferences as centralised versus joint scrutiny (Cooper 2016; Kreilinger 2015). But the far- 
reaching ideas, e.g. of the French Assemblée, that go beyond the lowest common denominator compromise underline the value of having three distinct models.

\section{Negotiations about the functioning of the Conference in 2012/13 and 2015}

This section tracks the negotiations between national parliaments and the European Parliament about how the Conference should function. Negotiations proceeded as follows: The first discussions took place from November 2012 onwards, in sub-groups of national parliaments (see section 4.1). The Speakers' Conference then agreed general organisational principles in April 2013 and, after little progress had been made in adopting Rules of Procedure, re-considered the issue and agreed 'principles for transposition into Rules of Procedure' in April 2015 (see section 4.2). The final round of negotiations about the Rules of Procedure took place at the meeting of the SECG Conference in November 2015 (see section 4.3).

\subsection{First discussions in sub-groups of national parliaments}

The Danish Folketing and the French Assemblée nationale have been particularly vocal actors in the ex-ante coordination of national parliaments' positions on their preferred institutional design of the Interparliamentary Conference of Article 13 TSCG which later became the SECG Conference (see Kreilinger 2015). These ad-hoc meetings in sub-groups among Speakers and committee chairpersons of national parliaments from November 2012 to April 2013 as well as the preparatory work at these meetings were crucial for advancing the discussion of fundamental issues concerning the arrangements of the Conference (Griglio and Lupo 2018).

On the one hand, the Danish Folketing and the chairperson of its European affairs committee, Eva Kjer Hansen, invited to two meetings on the subject in November 2012 and March 2013 (see Table 1). At their second meeting, the chairpersons of European affairs committees from 15 Member States declared their preference for 'establishing a small effective conference focused on substantial issues - to be held in the margins of the biannual COSAC-meetings' (Folketing 2013). The Conference on the basis of Article 13 
TSCG would not be a separate body, but an appendage to COSAC. The 15 chairpersons stated that they had 'no desire to build new inter-parliamentary bodies. [...] [E]xisting structures and resources should be exploited to their full potential' (Folketing 2013).

On the other hand, the French Assemblée nationale argued that it was 'necessary to implement this Conference as soon as possible, by taking the initiative to make specific proposals that engage in constructive negotiations with our European partners' (Assemblée nationale 2012: 65) and proposed to follow the model for CFSP and CSDP with 6 MPs per national parliament and 16 MEPs in order to accompany and control the European Semester. Inside the Conference, a specific Euro area 'component' should be established. While the entire Conference would follow the COSAC model, the French plans for the Euro area amount to creating a collective parliamentary counterweight (third mode). In January 2013, at a meeting that took place in Luxembourg, the Speakers of the national parliaments from the other five founding Member States ${ }^{\mathrm{VIII}}$ endorsed the proposals to implement the provision of Article 13 TSCG in that way (see Table 1). ${ }^{\text {IX }}$

Table 1: Preferences on interparliamentary cooperation under Article 13 TSCG

\begin{tabular}{|c|c|c|}
\hline DATE & AUTHOR(S) & KEY STATEMENT(S) \\
\hline \multirow{2}{*}{$\begin{array}{l}\text { NOV. } \\
2012\end{array}$} & $\begin{array}{l}\text { Chairpersons of } \\
\text { European affairs } \\
\text { committees of } 11 \\
\text { national } \\
\text { parliaments }\end{array}$ & $\begin{array}{l}\text { "worrying lack of proposals as to how the role of national parliaments can } \\
\text { be strengthened more concretely" (Folketing 2012) }\end{array}$ \\
\hline & $\begin{array}{l}\text { European } \\
\text { Parliament }\end{array}$ & $\begin{array}{l}\text { "the creation of a new mixed parliamentary body }[\ldots] \text { would be both } \\
\text { ineffective and illegitimate on a democratic and constitutional point of view" } \\
\text { (European Parliament 2012: 19) }\end{array}$ \\
\hline $\begin{array}{l}\text { JAN. } \\
2013\end{array}$ & $\begin{array}{l}\text { Speakers of } 6 \\
\text { national } \\
\text { parliaments }\end{array}$ & $\begin{array}{l}\text { "consider that }[\ldots] \text { a conference }[\ldots] \text { must be set up. }[\ldots][\mathrm{T}] \text { his conference } \\
\text { would discuss topical issues of Economic and Monetary Union, including } \\
\text { agreements in the framework of the European Semester, in order to } \\
\text { reinforce dialogue between the national Parliaments and with the European } \\
\text { Parliament" (National Parliaments 2013) }\end{array}$ \\
\hline $\begin{array}{l}\text { MARCH } \\
2013\end{array}$ & $\begin{array}{l}\text { Chairpersons of } \\
\text { European affairs } \\
\text { committees of } 15 \\
\text { national } \\
\text { parliaments }\end{array}$ & $\begin{array}{l}\text { "[w]e }[\ldots] \text { have no desire to build new inter-parliamentary bodies. Instead, we } \\
\text { believe that existing structures and resources should be exploited to their full } \\
\text { potential" (Folketing 2013) }\end{array}$ \\
\hline
\end{tabular}

Source: Own elaboration. 


\subsection{Two years of discussions and little progress}

In April 2013, the Speakers' Conference agreed on the general organisational principles for the Interparliamentary Conference of Article 13 TSCG $^{\mathrm{x}}$ (which, as noted, later became known as the SECG Conference), but the discussions between national parliaments and the European Parliament about the Rules of Procedure for the Conference lasted for another two years. Interestingly, the German Bundestag did not articulate an institutional position about the functioning of the Conference (Deubner 2013: 48), although its President took part in the meeting in Luxembourg in January 2013 and endorsed the resulting working paper. Only at a very late stage, in the run-up to its first meeting in Vilnius in October 2013, the German position was made clear in a letter by the Bundestag's Head of Delegation, Norbert Barthle (CDU). According to him, it would be 'premature' to seek the adoption of Rules of Procedure at that point, but he welcomed the idea to discuss the aims and functions of the Conference (Deutscher Bundestag 2013).

The constituent meeting of the Conference in October 2013 failed to agree on Rules of Procedures: The draft Rules of Procedure ${ }^{\mathrm{XI}}$, prepared by the Lithuanian Presidency Parliament, were not endorsed by the Conference. The Speakers' Conclusions of April 2013 therefore provided the procedural basis for the meetings of the Conference from October 2013 to November 2015.

In order to overcome the stalemate, the following Presidency Parliament (Greece) asked all parliaments for input. The internal organisation was again an item on the agenda of the September 2014 meeting of the Conference (organised by the Italian parliament), but no agreement was reached either and further discussions were postponed to 2015.

When the Speakers' Conference in Rome re-examined the issue of the Rules of Procedure of the 'Article 13 Conference' in April 2015, parliaments had already discussed for two years what the Conference should do and how it should be organised. The Speakers' Conclusions then changed its provisional name from 'Interparliamentary Conference on Economic and Financial Governance' into 'Interparliamentary Conference on Stability, Economic Coordination and Governance in the European Union' (see Table 2). This made the link to the TSCG (more) obvious. In addition to that, the Speakers 
agreed principles for transposition into Rules of Procedure at the next SECG Conference in Luxembourg in November 2015. These guidelines arguably left 'very little discretion' (Cooper 2017: 241) to the SECG Conference as the Speakers' Conference 'essentially dictated the terms' (ibid) of the Rules of Procedure.

Even though many of the Speakers' principles did not go beyond the common ground of previous agreements (see Table 2), two of them are noteworthy. First, the purpose of the Conference was defined more clearly: It

should provide a framework for debate and exchange of information and best practices in implementing the provisions of the Treaty in order to strengthen cooperation between national Parliaments and the European Parliament and contribute to ensuring democratic accountability in the area of economic governance and budgetary policy in the EU, particularly in the EMU, taking into account the social dimension and without prejudice to the competences of EU Parliaments. XII

Second, the Speakers referred to the timing of the Conference, a long-standing issue, and stated that meetings 'should be convened before the presentation of the Annual Growth Survey and the adoption of the National Reform Programmes ${ }^{\text {XIII }}$. The timing of the SECG Conference is of particular importance to make the voice of parliaments heard in the European Semester (see section 5, below). The provisions regarding the composition of delegations and meetings of the Conference remained unchanged (see Table 2). 
Table 2: Evolution of the Speakers' principles related to the SECG Conference

\begin{tabular}{|c|c|c|c|}
\hline & $\begin{array}{l}\text { EU SPEAKERS } \\
\text { CONFERENCE } \\
\text { APRIL } 2013 \\
\text { (NICOSIA) }\end{array}$ & $\begin{array}{l}\text { INTERMEDIATE } \\
\text { STEPS }\end{array}$ & $\begin{array}{c}\text { EU SPEAKERS } \\
\text { CONFERENCE } \\
\text { APRIL } 2015 \text { (ROME) }\end{array}$ \\
\hline $\begin{array}{l}\text { NAME } \\
\text { OF THE } \\
\text { CONFERENCE }\end{array}$ & $\begin{array}{l}\text { not defined / Conference } \\
\text { of Article } 13 \text { TSCG }\end{array}$ & $\begin{array}{l}\text { Interparliamentary } \\
\text { Conference on } \\
\text { Economic and } \\
\text { Financial Governance }\end{array}$ & $\begin{array}{l}\text { Interparliamentary Conference } \\
\text { on Stability, Economic } \\
\text { Coordination and Governance in } \\
\text { the European Union }\end{array}$ \\
\hline PURPOSE & $\begin{array}{l}\text { discuss budgetary policies } \\
\text { and other issues covered } \\
\text { by the TSCG (Article } 13 \\
\text { TSCG) }\end{array}$ & $\begin{array}{l}\text { [no consensus on the } \\
\text { propose of the Conference] }\end{array}$ & $\begin{array}{l}\text { - framework for debate and } \\
\text { exchange of information and best } \\
\text { practices } \\
\text { - contribute to ensuring } \\
\text { democratic accountability in the } \\
\text { area of economic governance and } \\
\text { budgetary policy }\end{array}$ \\
\hline COMPOSITION & \multicolumn{3}{|c|}{ Composition and size of delegations shall be determined by each Parliament. } \\
\hline MEETINGS & \multicolumn{3}{|c|}{$\begin{array}{l}\text { Twice a year; first semester: in Brussels; second semester: capital of the Parliament of } \\
\text { the Member State holding the rotating Council Presidency }\end{array}$} \\
\hline TIMING & not defined & not defined & $\begin{array}{l}\text { Conferences should be convened } \\
\text { before the presentation of the } \\
\text { Annual Growth Survey and } \\
\text { before the adoption of the } \\
\text { National Reform Programmes }\end{array}$ \\
\hline
\end{tabular}

Source: Own elaboration.

\subsection{Final negotiations on the Rules of Procedure in November 2015}

The adoption of the Rules of Procedure at the fifth meeting of the Conference on 10 November 2015 was thought to be a mere formality: A draft of the Rules of Procedure had been prepared by the Presidency Parliament (Luxembourg) and circulated to all other parliaments before the meeting. The final discussion of the draft of the Rules of Procedure was therefore supposed to take place in a short session among the Heads of the delegations at the end of the Conference.

But at that session, several of the provisions in the Rules of Procedure had been modified without prior notice and without making these changes visible. To the surprise of 
many delegations, the European Parliament was at the origin of these changes. The dispute grew sharply when the Head of the delegation of the European Parliament, Robert Gualtieri $^{\mathrm{XIV}}$, made it clear that the adoption of the Rules of Procedure would fail unless the amendments of the European Parliament were accepted. The Heads of many national delegations urged the representative of the European Parliament to pave the way for the unanimous adoption of the Rules of Procedure by dropping the amendments that had quietly found their way into the document. One technical change only clarified the term 'Presidency Parliament', but the provision on possible amendments to the Rules of Procedures, stating that these 'shall be subject to a decision by consensus by the Interparliamentary Conference on SECG’ (\$7.2), was adjusted by adding another phrase that these 'must be in accordance with the framework set by the Conference of Speakers of the EU Parliaments' ( $\$ 7.2 \mathrm{EP})$. It is clear that the European Parliament tried to consolidate and advance its legal interpretation of a SECG Conference that operates under the auspices of the Speakers' Conference (see section 2).

After the session had been suspended for 15 minutes to allow Mr Gualtieri to call his officials in Brussels (the President of the European Parliament was on an airplane to an EU summit in Valetta and could not be reached), the intensive mediation efforts succeeded in obtaining the necessary approval from the Head of delegation of the European Parliament on the Rules of Procedure. To that end, the request of the European Parliament to include a reference to the agreement on the framework for the SECG Conference reached by the Speakers' Conference in Rome in April 2015 was added in \$7.2. The Rules of Procedure were then adopted unanimously. $\$ 7.2$ now reads as follows:

Any amendments shall be subject to a decision by consensus by the Interparliamentary Conference on SECG, and must be in accordance with the framework set by the Conference of Speakers of the EU Parliaments. XV

\section{And the winner is...?}

Based on the tracking of interparliamentary negotiations in the previous section, this section evaluates the compromise on the Rules of Procedure as the outcome of an interparliamentary struggle that lasted from 2012 to 2015. Although an interparliamentary 
compromise, it is nevertheless possible to identify how the final provisions of the Rules of Procedure align with the three competing models for interparliamentary relations that were put forward in section 3 .

Profound disagreements, like the ones described in the previous section, are a common phenomenon in interparliamentary cooperation (see Fasone and Lupo 2016: 345-346). In the case of Article 13 TSCG, they concerned 'general questions of legitimacy, basic issues such as the formal weight to be given to the two parliamentary levels, and [...] the competences and objectives of such a conference' (Kreilinger 2014: 58). The underlying preferences about the institutional design of a body involved in the parliamentary scrutiny of EU Economic Governance (see section 3, above) prevented a smooth implementation of Article 13 TSCG: While the European Parliament clearly favoured an institutional design in which it would lead the scrutiny (first moded), the national parliaments were split between the second model of a COSAC-style conference and the third model of a collective parliamentary counterweight. Simon Sutour, the chairman of the European affairs committee in the French Sénat, described in 2013 that the European Parliament was putting 'pressure on other EU institutions to convince them that parliamentary oversight of the new governance is primarily ensured by itself (Sénat français 2013).

The first-hand evidence from participating observation in the final round of negotiations about the Rules of Procedure (see section 4.3) indicates how interparliamentary relations were still characterised by conflict and rivalry rather than cooperation (see Martucci 2017; Neunreither 2005). Some have argued that, just like for the CFSP/CSDP Interparliamentary Conference, 'overlapping authority claims' (HerranzSurrallés 2014) between the European Parliament and national parliaments can explain disagreements in Economic Governance to a great extent (e.g. Kreilinger 2015). According to Herranz Surralles' assessment of 'overlapping authority claims' (2014), the underlying explanation of the profound disagreements between national parliaments and the European Parliament is a mismatch between the daily EU policy making and formal treaty powers: an incremental and informal empowerment of the European Parliament clashes with national parliaments and their constitutional role linked to intergovernmental treaties and their domestic role in controlling national governments.

In the end, the SECG Conference has become a COSAC-style venue (second mode), although with some institutional peculiarities. The linkage to the European Parliamentary 
Week at the first annual meeting of the Conference and the absence of a provision regarding the size of delegations in the Rules of Procedure of the SECG Conference (which remain at the discretion of each parliament) are the most important ones. As a consequence, the second model did not fully prevail, but has been followed to a great extent. The SECG Conference certainly did not become a collective parliamentary counterweight against executive dominance in EU Economic Governance (third moded).

The final version of the Rules of Procedure essentially confirmed previously existing practices (Rozenberg 2017: 47), but in terms of their actual content, organisational arrangements in Rules of Procedure are important for assessing interparliamentary cooperation (see Hefftler and Gattermann 2015: 107-112). The Conference has a rotating (and not a permanent) secretariat. This means that it lacks dedicated resources of its own and is dependent on the respective Presidency Parliaments and the administration of the European Parliament (see Cooper 2017). In addition, a 'troika' of the current, preceding and upcoming Presidency Parliaments and the European Parliament plays a coordinating role through informal meetings which take place at the margins of the Conference ( $\$ 3.3$, \$3.4). In these respects, the Conference settled on a design similar to the cases of COSAC and the interparliamentary conference on foreign and defence policy (Winzen 2017: 26). As previously pointed out with respect to the Speakers' principles of April 2013, the new Conference

largely follows the characteristics of the 'standard' interparliamentary conference. The Speakers' decision did not have the ambition to be innovative, but rather to duplicate a model that worked in the past. (Kreilinger 2013: 19)

The size of delegations to the SECG Conference is, as noted above, not fixed ( $\$ 4.1$ of the Rules of Procedure, see also section 6, below).

Furthermore, the significance of the European Parliament's last-minute amendment to $\$ 7$ of the Rules of Procedure, as also explained by Ian Cooper (2017: 242), is that the SECG Conference may amend its Rules of Procedure, but must (always) adhere to the framework established by the Speakers' Conference. This strengthens the role of the Speakers' Conference which has, although it is not explicitly recognised by the EU Treaties, 
moved into an overall coordinating function for interparliamentary cooperation (Fasone 2016).

The real impact of the amendment remains to be seen: The current Rules of Procedure do not differ from the framework set by the Speakers' Conference in April 2015. If better working methods of the Conference (Griglio and Lupo 2018; Rozenberg 2017) can be applied without codification in the Rules of Procedure, the amendment will have no effect. But far-reaching changes to the Rules of Procedure, as for instance proposed by Valentin Kreilinger and Morgan Larhant (2016), become more difficult to implement. In terms of decision-making, $\$ 7.2$ of the Rules of Procedure represents a double-lock, as any changes to the Rules of Procedure must be adopted by consensus in the SECG Conference and, at the same time, also conform with the guidelines by the Speakers' Conference that were also adopted by consensus. Whether the European Parliament's insistence on that double-lock was necessary (or whether it has, on the contrary, led to a deterioration of interparliamentary relations) is another open question.

Regarding the timing and organisation of the meetings, in the first semester of each year, the Conference convenes in Brussels, co-hosted and co-presided by the Presidency Parliament and the European Parliament (\$3.1, Rules of Procedure). In the second semester of each year, it is held in the Member State holding the EU Presidency and presided over by the Presidency Parliament (\$3.1). The first of the two annual meetings of the SECG Conference is embedded into the so-called European Parliamentary Week. The creation of the European Parliamentary Week predates Article 13 TSCG and, in particular, contains a set of parallel interparliamentary sessions organised by different committees of the European Parliament and to a certain extent aligns with the model of EP-led scrutiny. The first meeting of the SECG Conference is therefore dominated by the European Parliament, although formally the Presidency Parliament co-chairs all sessions ( $\$ 3.1$. of the Rules of Procedure). Related to the overall timing of the Conference's two meetings per year, the Rules of Procedure state that they 'should be convened before the presentation of the Annual Growth Survey and the adoption of the National Reform Programmes’ (\$3.2). Here, the provisions in the Rules of Procedure also fully adhere to the Speakers' principles of April 2015 (see Table 2, above). The relevant stages of the European Semester are programmed for April (national governments must submit their Stability or Convergence Programme and National Reform Programme, in which they put forward their fiscal and 
economic policy, by the end of April) and November (the European Commission usually presents the Annual Growth Survey, which sets the overall economic priorities for the EU, by the end of November). ${ }^{\text {XVI }}$

If one looks at the issues that are put on the agenda of the SECG Conference, they have moved beyond budgetary policies and other issues covered by the TSCG, narrowly defined. In this respect, the Danish Folketing and its allies (see section 4.1) did not get their way. In February 2017, for instance, structural reforms, conditionality and the ESM programmes were addressed in one session; economic policy, social affairs, growth and jobs were covered at other meetings. Many centre-left parties, like the French Socialists (initially opposed to tighter budgetary surveillance), had supported the TSCG back in 2012 in exchange for a symbolic 'Pact for Growth and Jobs' that did not alter the fiscal rules (Rozenberg 2015: 7) and subsequently wanted to use the provision for creating the Interparliamentary Conference as a vehicle to counterbalance the dominant pro-austerity discourse in EU Economic Governance. This hope has not been fulfilled, but is still the reasoning behind some ideas to create a Parliamentary Assembly of the Euro area, e.g. in Thomas Piketty et al.'s 'Pour un traité de démocratisation de l'Europe' (Hennette et al. 2017).

Finally, according to the Rules of Procedure, '[t]he Presidency Parliament may present non-binding conclusions on the outcome of the meeting [...]. In the first semester of each year the latter may be presented together with the European Parliament' (\$6.1). The respective Presidency Parliaments have usually only presented a 'Presidency Summary' after the second meeting of the SECG Conference recapitulating the issues discussed in the different sessions. No conclusions have been issued after the meetings co-presided by the European Parliament. This means that the SECG Conference is not producing the same amount and the same type of written documentation as other interparliamentary conferences (e.g. COSAC and CFSP/CSDP).

The Conference thus suffers from some organisational and functional weaknesses. These realities must be taken into account in order to understand how the SECG Conference works on the basis of the status-quo in terms of its organisation. The institutional design of the Conference mostly corresponds to the second model of a COSACstyle venue. The interparliamentary compromise of November 2015 did not assign a direct European role to national parliaments (Winzen 2017: 121-175), but provides a possibility 
for undertaking joint scrutiny that is examined in the following section on the basis of attendance records at the Conference.

\section{An assessment of the SECG Conference on the basis of attendance records}

The SECG Conference has, by now, met ten times in total. Since the adoption of the compromise on the Rules of Procedure of the SECG Conference in November 2015, five meetings of the SECG conference have taken place (from February 2016 to February 2018). This allows taking stock of how the Interparliamentary Conference has worked in practice so far. On the basis of the previous findings, it is clear that the COSAC-inspired institutional design (second mode) prevailed, but attendance patterns can shed additional light on its development. After all, neither the size of national delegations, nor the affiliation of participants to certain parliamentary committees have been fixed; they remain the responsibility of each parliament. Article 13 TSCG, the Conclusions of the Speakers' Conference and $\$ 4.1$ of the Rules of Procedure only mention representatives of 'relevant committees':

The Interparliamentary Conference on SECG shall be composed of delegations from the relevant committees of the national Parliaments of EU Members States and the European Parliament. The composition and size of delegations shall be determined by each Parliament. ${ }^{\mathrm{XVII}}$

In the early years of its existence, the Conference was not able to meet far-reaching expectations by some actors and thus confirmed the difficulties encountered by all interparliamentary initiatives since 1989 (see Larhant 2005). But if assessed by the objective set in $\$ 2.1$ of its Rules of Procedure, according to which the Conference 'shall provide a framework for debate and exchange of information and best practices' and 'contribute to ensuring democratic accountability in the area of economic governance and budgetary policy in the EU, particularly in the EMU' ( $\$ 2.1$, Rules of Procedure), then the Conference actually does what it is supposed to do. After the procedural disagreements are resolved, national parliaments and the European Parliament could still embark on jointly scrutinising the executive decision-makers of EU Economic Governance. ${ }^{\text {XVIII }}$ 
Meeting with colleagues from other EU Member States is a firmly established part of the work of parliamentarians (see Wagner 2013: 195). In the following, this section examines variation over time (section 6.1), across Member States (section 6.2) and across committees (section 6.3). For each of the three dimensions, the attendance records from 2013 to 2018 are examined. The data have been extracted from the lists of participants.

\subsection{Variation over time}

SECG Conferences are usually attended by around 120 MPs when they take place in Brussels (as it is the case for the first meeting in connection with the European Parliamentary Week) and by around 90 MPs when they take place in the national capital of the Presidency Parliament (as it is the case for the second meeting). ${ }^{\mathrm{XIX}}$ From 2013 to 2018 a total of ten meetings of the Conference took place. There has been a slight decrease in the total number of participating MPs and in the average number of participants per national parliament (see Figure 1).

Figure 1: Overall attendance at the SECG Conference from 2013 to 2018

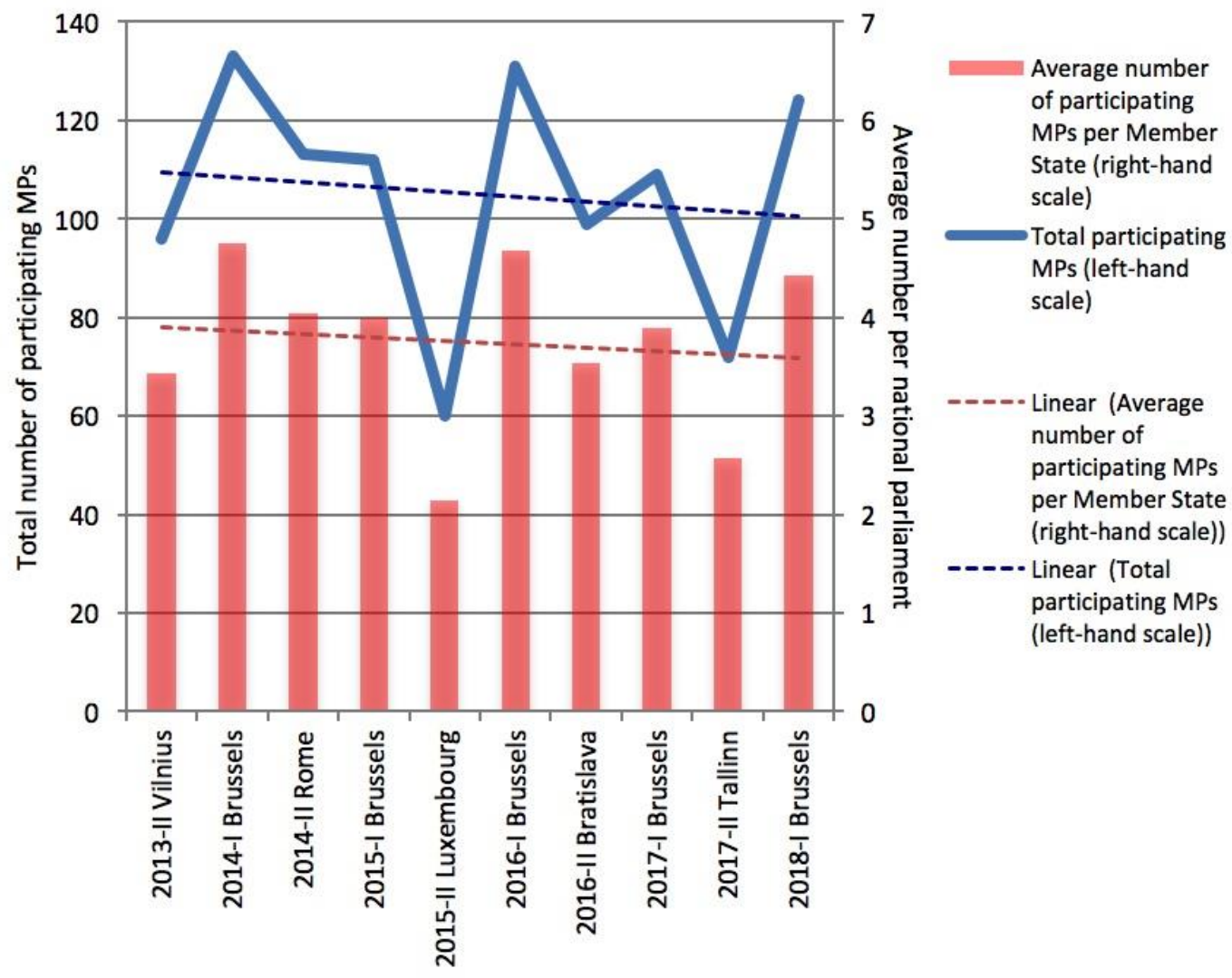


Source: Own elaboration. Data: Fromage (2016a), Annex I, for 2013(II)-2015(I); own data collection from lists of participants for 2015(II)-2018(I).

In general, however, the attendance can be considered stable. After an all-time low at the meeting in Luxembourg in November 2015 (60 MPs), the number of participants has recovered at the following meetings (see Figure 1). This means that despite struggles about the Rules of Procedure, attendance has not declined. Parliamentarians thus remain attached to the Conference that corresponds to the second model. They dedicate time and resources to it.

\subsection{Variation across member states}

The data also confirm that over the years interparliamentary relations between national parliaments have 'not develop[ed] into a balanced multilateral interplay including parliaments from all member states on the same footing' (Benz 2011: 11). Similar to the case of COSAC (Kreilinger 2013: 4), national parliaments' participation in the early years of the SECG Conference was unequal (Fromage 2016a) and the great variation in the number of MPs attending the SECG Conference has persisted (see Figure 2). If the average participation is below two MPs (as for Denmark, Croatia, the United Kingdom, Slovenia and Bulgaria), the delegation of a national parliament does not allow for representation of governing parties and opposition parties - not to mention representation of both chambers in case of bicameral systems. At the same time, it is clear that MPs have limited time and resources for the SECG Conference. They may also already feel well-informed. Since the creation of the Conference in 2013, only 13 out of 28 national parliaments have had average delegation sizes of four or more MPs. Four MPs is generally considered the ideal number of MPs in order to have a 'solid foundation for a genuine network of high flyer specialists' (Rozenberg 2017: 50), where the chair and deputy chair of the Budget or Finance committee, belonging to different political camps (and assemblies in case of bicameral systems), would be represented. Unsurprisingly, the national parliaments of the biggest Euro area members (France, Germany and Italy) have, on average, sent large delegations of seven or more MPs to the SECG Conference (see Figure 2). 
Figure 2: Attendance per national parliament at the SECG Conference from 2013 to 2018

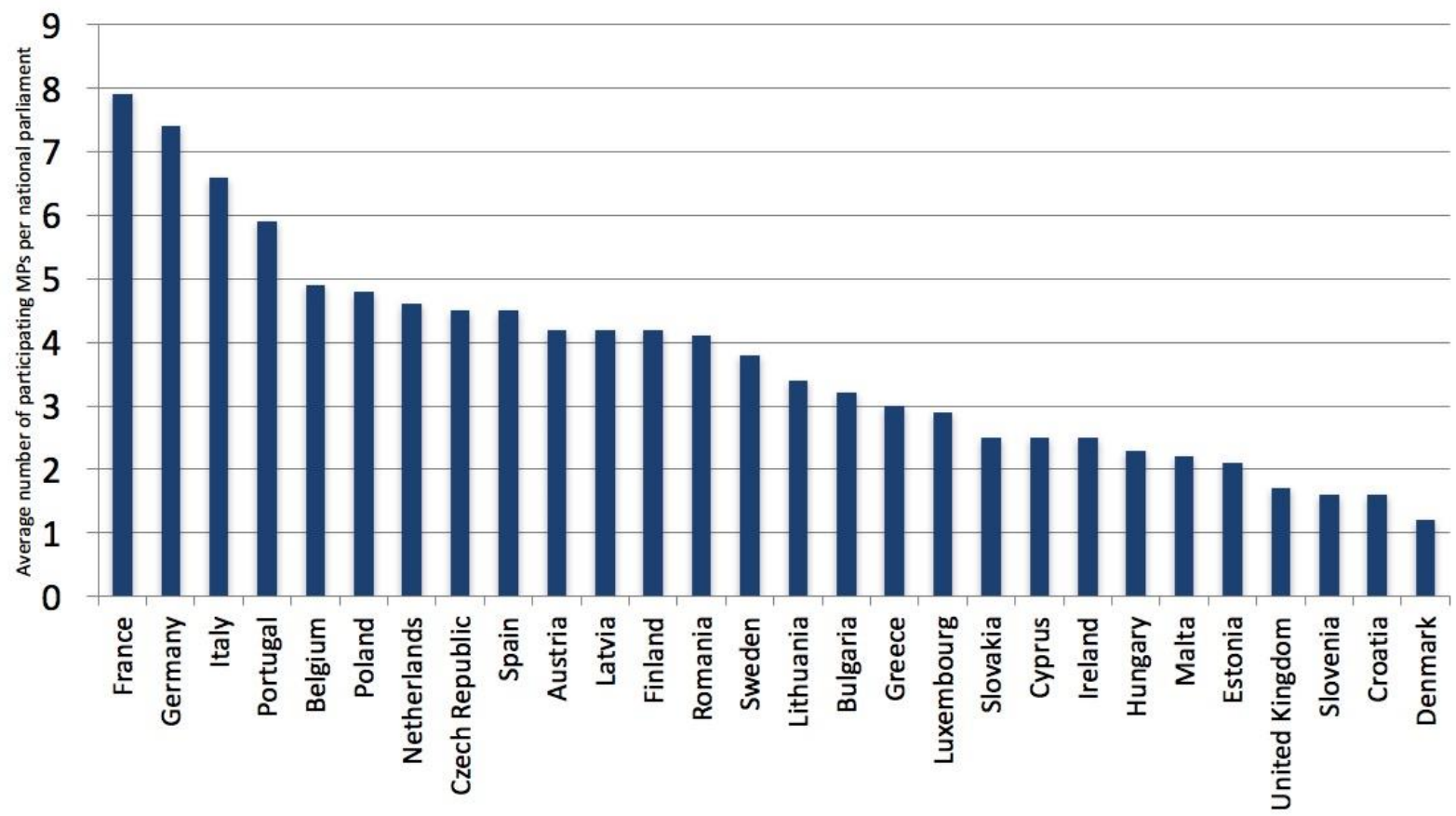

Source: Own elaboration based on data collection from lists of participants.

Delegation sizes also vary in other interparliamentary settings. As long as the SECG Conference is not asked to take binding decisions, such a variation is not a problem. If, at some point, the SECG Conference evolved into this direction, different delegation sizes (or voting powers) might be necessary in order to ensure an equal representation of citizens from EU member states.

\subsection{Variation across committees}

Finally, one interparliamentary struggle in the early negotiations about the institutional design of the Conference concerned the role of European affairs committees. The institutional self-interest of European affairs committees was to keep control over Economic Governance and possibly avoid an empowerment of their fellow MPs who are 
most likely to come from Budget or Finance committees. They did not succeed, although in 2012/2013, the Danish Folketing was able to build a large coalition among the chairpersons of European affairs committees (see section 4.1). ${ }^{\mathrm{xx}}$

The lists of participants allow examining the committee affiliation of participating MPs and whether MPs affiliated to sectoral committees (e.g. Budget or Finance committees) or MPs affiliated to European affairs committees attend the Conference. This has evolved over time (see Figure 3): At the constituent meeting of the Conference in Vilnius in October 2013, roughly 50\% of the participating MPs belonged to the Budget or Finance committees of their national parliament, $28 \%$ were affiliated to the European affairs committee and the remaining participants (over 20\%) were members of other sectoral committees such as Economic or Social affairs. ${ }^{\text {XxI }}$ In November 2015, about 33\% (+5 percentage points compared to the constituent meeting in 2013) of the MPs attending the Conference were members of European affairs committees, 44\% (-6) were members of Budget or Finance committees and 23\% (+3) of participating MPs did not belong to either of these two committees (Kreilinger 2016: 49). More recently, at the meeting in Tallinn in October 2017, only 17\% of participating MPs belonged to the European affairs committee of their national parliament (-16 compared to the meeting in Luxembourg, two years earlier); $83 \%$ of them were affiliated to other sectoral committees. This proportion of European affairs committee members has recovered slightly to $23 \%$ at the most recent meeting in Brussels in February 2018 (see Figure 3).

Figure 3: Committee-affiliation of MPs at the SECG Conference from 2015 to 2018 


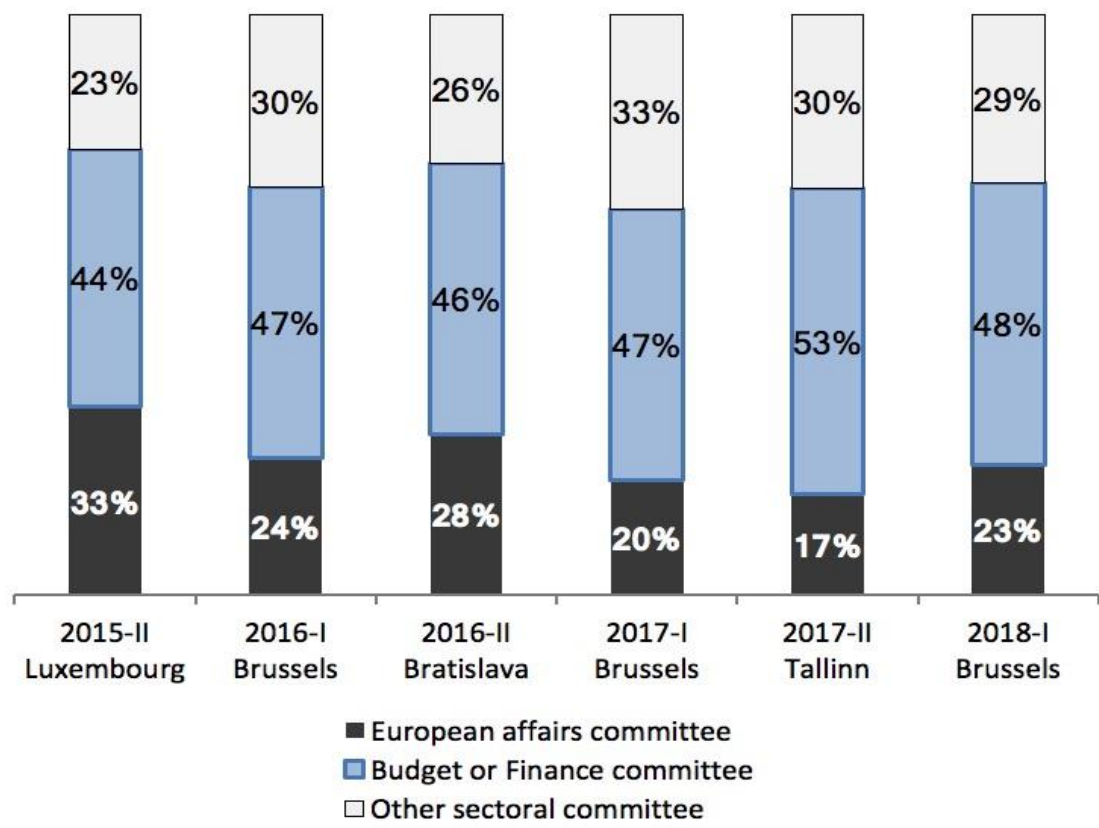

Source: Own elaboration based on data collection from lists of participants.

This suggests that the euro crisis has not only affected the power balance within national parliaments (Fasone 2018), but also interparliamentary cooperation and a 'mainstreaming' of EU affairs (see Gattermann et al. 2016) has taken place at the SECG Conference through a greater involvement of MPs from sectoral committees (Fromage 2016b; Rozenberg 2017: 48): If MPs who cover budget or finance issues become involved in interparliamentary cooperation, the domestic experts on the topic become active at the EU level (and not primarily MPs from European affairs committees that are already quite Europeanised). This strengthens what has been called 'interparliamentarism by committee' (Fasone and Lupo 2016: 355) and exposes MPs from sectoral committees to the positions and views of parliamentarians from other EU countries.

\section{Conclusion}

This article has examined the difficulties in making interparliamentary cooperation work. The Rules of Procedure of the SECG Conference reflect a lowest common denominator compromise about the role that this new body should play in EU Economic Governance. In that respect, the findings are in line with previous theoretical assumptions 
about and practical examples for challenges in interparliamentary cooperation (Crum and Fossum 2013a; Lupo and Fasone 2016).

National parliaments and the European Parliament agreed that the institutional design of the SECG Conference would follow the model of COSAC, although with two institutional peculiarities: The linkage to the European Parliamentary Week at the first annual meeting gives the European Parliament some additional leverage and there is no provision regarding the size of delegations. Thus, the second model did not fully prevail, but it has been followed to a great extent. The SECG Conference certainly did not become a collective parliamentary counterweight to executive dominance in Economic Governance (third model. Despite this, the number of participants is stable over time, the size of national delegations continues to vary and MPs are still twice as likely to be members of Budget or Finance committees than to be members of European affairs committees.

After two years of procedural disagreements, the Rules of Procedure are the current basis on which the Conference works and interparliamentary cooperation in the post-crisis Economic Governance is now characterised by a high degree of stability. The SECG Conference could still become a venue for joint scrutiny in EU Economic Governance in which national parliaments and the European Parliament cooperate in order to remedy the information asymmetries that they have vis-à-vis the executives. MPs and MEPs would then engage in a real dialogue with representatives of the EU's executive and jointly scrutinise those actors and bodies who are responsible for EU Economic Governance. But despite proposals for creating some kind of joint parliamentary body, there is currently little momentum in that direction.

\footnotetext{
*Valentin Kreilinger is Research Fellow at the Jacques Delors Institute Berlin, Centre for European Affairs at the Hertie School of Governance, kreilinger@delorsinstitut.de. An earlier draft of this article was prepared for the workshop 'The European Union's Inter-Parliamentary Conferences: between theory and practice', organised by the Centre for Parliamentary Studies of LUISS Guido Carli University in Rome on 15 May 2017. The author would like to thank Ben Crum, Elena Griglio, Stelios Stavridis and the anonymous reviewers for insightful comments.

I Article 13 TSCG.

II Article 13 TSCG.

III 'the organisation and promotion of effective and regular inter-parliamentary cooperation within the Union shall be determined by the European Parliament and National Parliaments.'

IV Article 12 TEU. The crisis thus only accelerates a process that was already foreseen in the Lisbon Treaty.

V E.g. the Four Presidents' Report (2012) and the Five Presidents' Report (2015) on completing EMU.

VI COSAC is the Conference of Parliamentary Committees for Union Affairs of Parliaments of the EU which was established in 1989.

VII This would be less far-reaching than a 'Eurozone Parliament' (see Kreilinger and Larhant 2016).

VIII Belgium, France, Germany, Italy, Luxembourg and the Netherlands.
} 
Ix Working Paper of the meeting of the Speakers of Parliament of the Founding Member States of the European Union and the European Parliament in Luxembourg on January 11th, 2013. The Chamber of Deputies of the Republic of Italy did not participate in the meeting and did not endorse the document.

x Presidency conclusions of the Speakers Conference, Nicosia, April 2013.

xI Parliament of Lithuania, Draft Rules of Procedure of the Interparliamentary Conference on Economic and Financial Governance of the European Union, 2013.

XII Presidency conclusions of the Speakers Conference, Rome, April 2015, p. 5.

XIII Presidency conclusions of the Speakers Conference, Rome, April 2015, p. 6.

XIV Chairman of the Committee for Economic and Monetary affairs in the European Parliament.

xv Rules of Procedure of the Interparliamentary Conference on Stability, Economic Coordination and Governance in the European Union.

XVI The SECG Conference could also be linked to different stages of the European Semester by taking place 'in November or December after the Annual Growth Survey is presented and in June after country-specific recommendations are issued' (Rozenberg 2017: 47-48).

XVII $\$ 4.1$ of the Rules of Procedure.

XVIII Joint scrutiny means that national parliaments and the European Parliament cooperate in order to remedy the information asymmetries that they have vis-à-vis the executives.

XIX Own calculation on the basis of lists of participants.

xx Chairpersons from 15 national parliaments/chambers (Czech Republic, Denmark, Estonia, Ireland, Hungary, Latvia, Lithuania, Luxembourg, Slovakia, Slovenia, Sweden, the UK House of Lords, the Belgian Senate and the Romanian Senate signed a letter in April 2013 arguing that the Article 13 Conference should meet at the margins of COSAC (Folketing 2013, see also Table 1).

xxI Own calculation on the basis of the list of participants.

\section{References}

- Assemblée nationale, 2012, 'Rapport d'information sur le projet de loi de ratification du Traité sur la stabilité, la coordination et la gouvernance au sein de l'Union économique et monétaire', $\mathrm{N}^{\circ} 202$, Assemblée nationale, Paris.

- Bengtson Christina, 2007, 'Interparliamentary cooperation within Europe', in O'Brennan John and Raunio Tapio (eds), National Parliaments within the Enlarged European Union, Routledge, London, 46-65.

- Benz Arthur, 2011, 'Linking Multiple Demoi: Inter-parliamentary Relations in the EU', Hagener OnlineBeiträge zu den Europäischen Verfassungswissenschaften, XII(1).

- Cooper Ian, 2016, "The politicization of interparliamentary relations in the EU: Constructing and contesting the "Article 13 Conference" on economic governance', Comparative European Politics, XIV(2): 196214.

- Cooper Ian, 2017, 'The Emerging Order of Interparliamentary Cooperation in the Post-Lisbon EU', in Jancic Davor (ed), National Parliaments after the Lisbon Treaty and the Euro Crisis, Oxford University Press, Oxford, 227-246.

- Costa Olivier and Latek Marta, 2001, 'Paradoxes and limits of interparliamentary cooperation in the European Union', Journal of European Integration, XXIII(2): 139-164.

- Crum Ben, 2018, 'Parliamentary accountability in multilevel governance: what role for parliaments in post-crisis EU economic governance?', Journal of European Public Policy, XXV(2): 268-286.

- Crum Ben and Fossum John E., 2009, 'The Multilevel Parliamentary Field: a framework for theorizing representative democracy in the EU', European Political Science Review, I(02): 249-271.

- $\quad$ Crum Ben and Fossum John E., 2013a, 'Conclusion: Towards a Democratic Multilevel Parliamentary Field?', in Crum Ben and Fossum John E. (eds), Practices of inter-parliamentary coordination in international politics the European Union and beyond, ECPR Press, Colchester, 251-268.

- Crum Ben and Fossum John E., 2013b, 'Practices of interparliamentary coordination in international politics: the European Union and beyond', in Crum Ben and Fossum John E. (eds), Practices of interparliamentary coordination in international politics the European Union and beyond, ECPR Press, Colchester, 1-14. 
- Curtin Deirdre, 2014, 'Challenging Executive Dominance in European Democracy', The Modern Law Review, LXXVII(1): 1-32.

- Dawson Mark and de Witte Floris, 2013, 'Constitutional Balance in the EU after the Euro-Crisis', The Modern Law Review, LXXVI(5): 817-844.

- Deubner Christian, 2013, The Difficult Role of Parliaments in the Reformed Governance of the Economic and Monetary Union, Foundation for European Progressive Studies.

- Deutscher Bundestag, 2013, 'Letter by the Head of the German delegation, Nobert Barthle', http://renginiai.lrs.lt/renginiai/EventDocument/0f6147e3-6125-40b9-93d8edc7c31e085f/Barthle Lithuanian $\% 20$ Presidency EN courtesy $\% 20$ translation.pdf.

- Esposito Antonio, 2016, 'The Role of COSAC in EU Interparliamentary Cooperation: An (Endless) Quest for an Identity', in Lupo Nicola and Fasone Cristina (eds), Interparliamentary Cooperation in the Composite European Constitution, Hart Publishing, Oxford, 325-333.

- European Parliament, 2012, Report with recommendations to the Commission on the report of the Presidents of the European Council, the European Commission, the European Central Bank and the Eurogroup 'Towards a genuine Economic and Monetary Union'.

- Fabbrini Sergio, 2013, Intergovermentalism and its Outcomes: the Implications of the Euro Crisis on the European Union, LUISS School of Government.

- Fasone Cristina, 2012, The struggle of the European Parliament to participate in the new Economic Governance, RSCAS 2012/45, EUI Working Papers.

- $\quad$ Fasone Cristina, 2016, 'Ruling the (Dis-)order of Interparliamentary Cooperation? The EU Speakers' Conference', in Lupo Nicola and Fasone Cristina (eds), Interparliamentary Cooperation in the Composite European Constitution, Hart Publishing, Oxford, 269-289.

- Fasone Cristina, 2018, 'Has Euro-crisis law affected the power balance in national parliaments? A comparative analysis on the role of committees', Politique européenne, LIX(1): 24-57.

- Fasone Cristina and Lupo Nicola, 2016, 'Conclusion. Interparliamentary Cooperation in the Framework of a Euro-national Parliamentary System', in Lupo Nicola and Fasone Cristina (eds), Interparliamentary Cooperation in the Composite European Constitution, Parliamentary Democracy in Europe, Hart Publishing, Oxford, 345-360.

- Folketing, 2013, 'Joint letter of 15 Chairpersons of European Affairs Committees to the Speakers' Conference, 08/04/2013', $<$ www.ipex.eu/IPEXLWEB/dossier/files/download/082dbcc53dbcb6ed013e07d2d31930a6.do>.

- Fromage Diane, 2016a, 'Standing Committees in Interparliamentary Cooperation in the Post-Lisbon Era: Towards the End of the European Affairs Committee's Predominance?', in Lupo Nicola and Fasone Cristina (eds), Interparliamentary Cooperation in the Composite European Constitution, Hart Publishing, Oxford, 113130.

- $\quad$ Fromage Diane, 2016b, European Economic Governance and Parliamentary Involvement: Some Shortcomings of the Article 13 Conference and a Solution, Les Cahiers européens $N^{\circ} 01 / 2016$, Centre d'Etudes européennes de Sciences Po.

- Gattermann Katjana, Högenauer Anna-Lena, and Huff Ariella, 2016, 'Research note: studying a new phase of europeanisation of national parliaments', European Political Science, XV(1): 89-107.

- Griglio Elena and Lupo Nicola, 2018, 'The Conference on Stability, Economic Coordination and Governance: Filling the Gaps of Parliamentary Oversight in the EU', Journal of European Integration, XL(3): 358-373.

- Hallerberg Mark, Marzinotto Benedicta, and Wolff Guntram B., 2018, 'Explaining the evolving role of national parliaments under the European Semester', Journal of European Public Policy, XXV(2): 250-267.

- Hefftler Claudia and Gattermann Katjana, 2015, Interparliamentary Cooperation in the European Union: Patterns, Problems and Potential', in Hefftler Claudia, Neuhold Christine, Rozenberg Olivier, and Smith Julie (eds), The Palgrave Handbook of National Parliaments and the European Union, Palgrave Macmillan, Basingstoke, 94-115.

- Hennette Stéphanie, et al., 2017, Pour un traité de démocratisation de l'Europe, Éditions du Seuil, Paris.

- Herranz-Surrallés Anna, 2014, 'The EU's Multilevel Parliamentary (Battle)Field: Inter-parliamentary Cooperation and Conflict in Foreign and Security Policy', West European Politics, XXXVII(5): 957-975. 
- Hix Simon, 2014, 'Democratizing a Macroeconomic Union in Europe', in Cramme Olaf and Hobolt Sara B. (eds), Democratic Politics in a European Union Under Stress, Oxford University Press, Oxford, 180-198.

- Jančić Davor, 2016, 'National Parliaments and EU Fiscal Integration', European Law Journal, XXII(2): 225-249.

- Kreilinger Valentin, 2013, The new Inter-parliamentary Conference on Economic and Financial Governance, Policy Paper n¹00, Notre Europe - Jacques Delors Institute.

- Kreilinger Valentin, 2014, 'Possibilities for Upgrading Inter-parliamentary Cooperation after the 2014 European Elections', Polish Quarterly of International Affairs, XXIII(1): 57-68.

- Kreilinger Valentin, 2015, 'Inter-parliamentary cooperation and its challenges: The case of Economic and Financial Governance', in Fabbrini Federico, Ballin Ernst Hirsch, and Somsen Hans (eds), What Form of Government for the EU and the Eurozone?, Hart Publishing, Oxford, 271-288.

- Kreilinger Valentin, 2016, National parliaments, surveillance mechanisms and ownership in the Euro Area, Studies and Reports n¹10, Jacques Delors Institut - Berlin.

- Kreilinger Valentin and Larhant Morgan, 2016, Does the Eurozone need a Parliament?, Policy Paper $n^{\circ} 176$, Jacques Delors Institut - Berlin.

- Larhant Morgan, 2005, La coopération interparlementaire dans l'UE. L’heure d'un nouveau départ?, Policy Paper, Notre Europe.

- Lupo Nicola and Fasone Cristina, 2016, Interparliamentary Cooperation in the Composite European Constitution, Hart Publishing, Oxford.

- Martucci Francesco, 2017, 'The Democratic Foundations of the EMU: The European Parliament and the National Parliaments Between Cooperation and Rivalry', in Daniele Luigi, Simone Pierluigi, and Cisotta Roberto (eds), Democracy in the EMU in the Aftermath of the Crisis, Springer International Publishing, Cham, 2750 .

- Neunreither Karlheinz, 1994, 'The Democratic Deficit of the European Union: Towards Closer Cooperation between the European Parliament and the National Parliaments', Government and Opposition, XXIX(3): 299-314.

- Neunreither Karlheinz, 2005, 'The European Parliament and National Parliaments: Conflict or cooperation?', The Journal of Legislative Studies, XI(3-4): 466-489.

- Neyer Jürgen, 2014, Justified Multi-level Parliamentarism: Situating National Parliaments in the European Polity', The Journal of Legislative Studies, XX(1): 125-138.

- Raimla E., 2016, Involvement of the National Parliaments in SCPs and NRPs - 2014, 2015 and 2016, European Parliament Directorate-General for Internal Policies, Economic Governance Support Unit.

- Raunio Tapio, 2014, 'Legislatures and Foreign Policy', in Martin Shane, Saalfeld Thomas, and Strøm Kaare (eds), The Oxford Handbook of Legislative Studies, Oxford University Press, Oxford, 543-566.

- Rozenberg Olivier, 2015, La France à la recherche d'un récit européen, Question d'Europe no. 345, Fondation Robert Schuman.

- Rozenberg Olivier, 2017, The Role of the National Parliaments after Lisbon: Potentialities and Challenges, Study requested by the AFCO committee, European Parliament.

- Rozenberg Olivier and Hefftler Claudia, 2015, 'Introduction', in Hefftler Claudia, Neuhold Christine, Rozenberg Olivier, and Smith Julie (eds), The Palgrave Handbook of National Parliaments and the European Union, Palgrave Macmillan, London, 1-39.

- Schmidt Vivien A., 2015, 'Forgotten Democratic Legitimacy: "Governing by the Rules" and "Ruling by the Numbers"', in Matthijs Matthias and Blyth Mark (eds), The Future of the Euro, Oxford University Press, New York, 90-115.

- Schöne Helmar, 2005, 'Die teilnehmende Beobachtung als Datenerhebungsmethode in der Politikwissenschaft. Methodologische Reflexion und Werkstattbericht', Historical Social Research/Historische Sozialforschung: 168-199.

- $\quad$ Sénat français, 2013, 'Compte rendu de la Commission des affaires européennes, 31 janvier 2013', http://www.senat.fr/compte-rendu-commissions/20130128/europ.html.

- Wagner Wolfgang, 2013, 'Who is Coming? Attendance Patterns in the NATO and WEU Parliamentary Assemblies', in Crum Ben and Fossum John E. (eds), Practices of inter-parliamentary coordination in international politics the European Union and beyond, ECPR Press, Colchester, 195-212. 
- Winzen Thomas, 2017, Constitutional Preferences and Parliamentary Reform: Explaining National Parliaments' Adaptation to European Integration, Oxford University Press, Oxford.

- Winzen Thomas, Roederer-Rynning Christilla, and Schimmelfennig Frank, 2015, 'Parliamentary coevolution: national parliamentary reactions to the empowerment of the European Parliament', Journal of European Public Policy, XXII(1): 75-93. 